Premiere Educandum: Jurnal Pendidikan Dasar dan Pembelajaran

Volume 11 (1) 58 - 74 June 2021

ISSN: 2088-5350 (Print) / ISSN: 2528-5173 (Online)

Doi: $10.25273 /$ pe.v11i1.7843

The article is published with Open Access at: http://e-journal.unipma.ac.id/index.php/PE

\title{
Because the sky is the limit: Interpretive phenomenological analysis of millennial elementary school teachers using digital technology in the classroom
}

\author{
Dian Veronika Sakti Kaloeti $\bowtie$, Universitas Diponegoro \\ Rouli Manalu, Universitas Diponegoro \\ $\bowtie$ dvs.kaloeti@live.undip.ac.id
}

\begin{abstract}
The millennials who work as elementary school teachers are currently increasing because it replaces the previous generation who will retire. This generation grows surrounded by technology and educates technology savvy too. This study aims to explore millennial teachers' experience related to the use of technology in learning in primary schools. Two research questions were proposed: 1) How did millennial teachers experience their role as teachers for elementary school students; 2) What is millennial teacher's experience when using technology in learning for students in elementary schools. This study uses a qualitative method with the Interpretative Phenomenological Analysis (IPA) approach. Semi-structured interviews with open-ended questions were conducted on 6 elementary school teachers. The analysis showed four emergent themes, namely: (1) Interpersonal experience; (2) Technology as a learning tool; (3) Barriers to integrating technology in learning; (4) Strategy to overcome obstacles. Collaborative, and collegial relationships will help the subject to make an active contribution at work. Familiarity with technology helps millennial teachers in innovating learning and interacting with students.
\end{abstract}

Keywords: Millennial teachers, elementary school, learning technology, interpretative phenomenological analysis

Received 19 November 2020; Accepted 13 March 2021; Published 01 June 2021

Citation: Kaloeti, D. V. S. \& Manalu, R. (2021). Because the sky is the limit: Interpretive phenomenological analysis of millennial elementary school teachers using digital technology in the classroom. Premiere Educandum: Jurnal Pendidikan Dasar dan Pembelajaran, 11(1), 58 - 74.

Doi.org/10.25273/pe.v11i1.7843

\section{(cc) BY-NC-SA}

Copyright (C)2021 Premiere Educandum: Jurnal Pendidikan Dasar dan Pembelajaran Published by Universitas PGRI Madiun. This work is licensed under the Creative Commons Attribution-NonCommercialShareAlike 4.0 International License. 


\section{INTRODUCTION}

The development of technology and its connection with all aspects of human life make change happen quickly, including in the primary education sector. Coomes \& Debard (2004) referred to this time as uncertain times, where the experience of human interaction with technology and innovation will shape human life, which is a very dynamic development. Education as a forum for shaping the nation's generation is expected to align with technological developments by making learning innovations that involve technology.

As an essential element in education, teachers are expected to be adaptive and responsive to changes caused by uncertain times (Laughter, 2011; Silverman, 2010). Teachers have a role in developing connectedness with students through learning experiences that will prepare them to enter a rapidly developing world (fast-paced world) (Horn, Staker, \& Christensen, 2014; Staker \& Horn, 2012).

Next, Batz, Olsen, Dumont, Dastoor, \& Smith (2017) stated that school's current situation is that teachers known as traditionalists or the silent generation will soon retire and be replaced by younger teachers who come from the millennial generation. Millennial teachers were born in the mid-1980s to early 2000s (Howe \& Strauss, 2000).

Data from the Ministry of Education and Culture shows that in 2019, the number of elementary school teachers in Indonesia was 1,467,461. Central Java has a percentage spread of $10.89 \%$ of the total primary school teachers in Indonesia. The number of teachers between the ages of 24-39 years is around 160, 750 people (Kemdikbud, 2019). Based on this data, it can be concluded that around 11\% of the primary school teacher population in Central Java is the millennial generation.

Bennett dan Levinthal (2017) predicts that millennials dominate as many as $70 \%$ of the global job market. Millennial or digital natives are often referred to as NextGen, Echo Boomers (Smith, 2013). This generation grew up surrounded by technology and uses it instinctively in everyday life (Joiner et al., 2013; Smith, 2013). Millennial teachers are described as digitally conscious groups who use technology in learning instruction (Attard \& Orlando, 2014). In research by Flanagan dan Shoffner (2013), It was found that millennial teachers understand technology integration is essential in teaching the current generation.

Obtaining a description of teacher knowledge about technology is very important concerning to the success of the current generation of student learning processes (Ertmer, Ottenbreit-Leftwich, Sadik, Sendurur, \& Sendurur, 2012; Horn et al., 2014). Teacher trust in effective learning methods then correlates with the technology integration in teaching and learning activities (Keren-kolb, 2013; C. Kim, Kim, Lee, Spector, \& DeMeester, 2013). Research conducted by (Chiu \& Churchill, 2015) found teachers' anxiety when using technology in learning activities. This feeling of anxiety arises in connection with the teacher's mastery of the device or media used, the suitability of the subjects with the learning media, and the concern about increasing the workload due to technology use. Apart from that in research conducted by Shatto dan Erwin (2016) mentions, today's attention span is only 12 seconds, so teachers must package the learning as attractive as possible by applying several pauses or interspersed with games or jokes to keep them focused.

On the other hand, this millennial teacher is also closely related to adaptation issues because he/she is a fresh graduate who has just entered the world of work. Kaifi, et.al. (2012) also added that those who are millennial teachers have less than five years of teaching experience, so they are still said to be beginner teachers.

Research by Klassen, Frenzel, and Perry (2012) stated that an essential element of elementary school teachers is feeling comfortable with the setting of the classroom environment and adapting the use of existing facilities and infrastructure in schools.

Another problem that arises for millennial teachers is the inability to integrate their technical knowledge with the pedagogical abilities used in classroom learning. (Kirkwood 
\& Price, 2014) which will be further strengthened if the technology facilities in the school environment are still limited.

Based on the regulation of the Minister of National Education of the Republic of Indonesia, number 16 of 2007 concerning academic qualification standards and teacher competence (Kemendikbud, 2007), a teacher must have a standard of pedagogical competence, personal competence, social competence, and professional competence. There are many ways that millennial teachers use to achieve all these competencies while still using technology as a learning medium to suit the times.

This study explores millennial teacher experiences related to the use of technology in learning in elementary schools. Two research questions were posed, namely: 1) How do novice millennial teachers deepen their role as teachers for elementary school students; 2 ) How is the experience of millennial teachers when using technology in learning for students in elementary schools?

This study will provide insight into understanding from the point of view of novice millennial teachers about their experiences as teachers and interactions with the use of technology in learning. This research will increase understanding of the ways that novice millennial teachers adapt and overcome obstacles that arise. Furthermore, the results of this study can be used by schools as material for mentoring and self-development programs for beginner millennial teachers.

\section{METHOD}

\section{Research design}

This study uses an Interpretative Phenomenological Analysis (IPA) perspective. Phenomenological studies describe several individuals' general meaning to various life experiences related to concepts or phenomena (Creswell, 2015). According to Husserl (in LaKahija, 2017) phenomenologists emphasize the subject's direct experience, so that phenomenological researchers must be able to see the subject's direct experience. Husserl refers to the term epoche, in which the researcher eliminates presumptions, assumptions, or speculations in the researcher, so that the researcher can see the essence of the subject's experience clearly. In this study, the main experiences explored were regarding the role of beginner millennial teachers in elementary schools and millennial teachers' experiences when using technology in learning. Further explanation regarding the research design can be seen in Figure 1.

\section{Participants}

The collection of participants in this study used a purposive sampling technique, in which the participants were selected using the researcher's criteria. The criteria for the inclusion of participants in this study were teachers with an age range of 23-38 years or millennial generation (Dimmock, 2019); who has worked in elementary school for one year because the development of organizational commitment will be seen after six months of individuals joining the O'Driscoll organization (in Ulfah, 2016); and willing to be a research participant proven by signing the informed concent.

The steps for selecting participants were carried out by visiting the school where the research was conducted, licensing the research implementation, and selecting participants according to the research inclusion criteria. Participants in this study were six public elementary school teachers in Semarang. The information about participants can be seen in Table 1. 


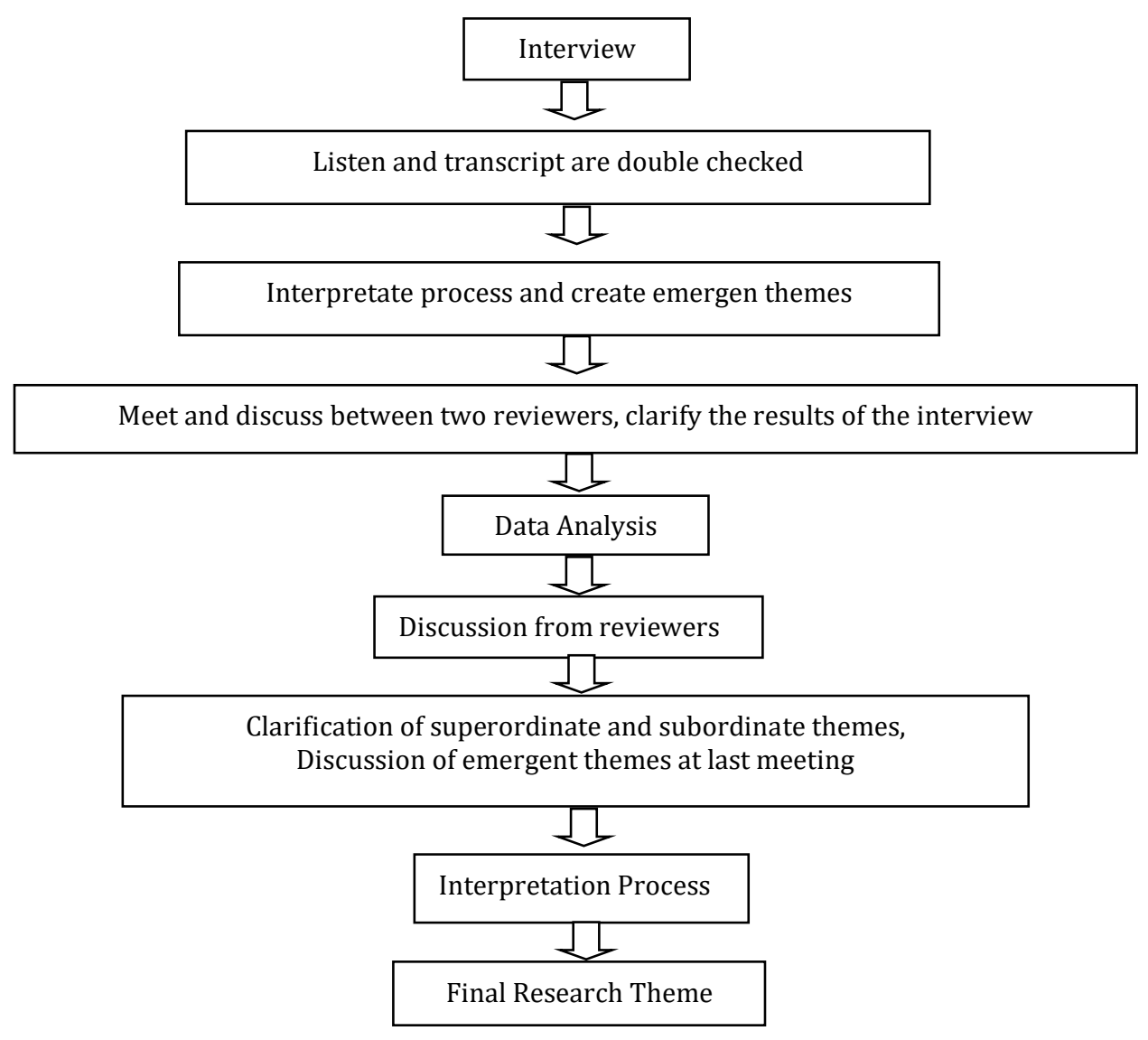

Figure 1. Research design

TABLE 1. Information about participants

\begin{tabular}{|c|c|c|c|c|c|}
\hline No & Name & Age & Gender & Length of Work & Status \\
\hline 1 & IM & 35 & Women & 8 years 2 monts & $\begin{array}{l}\text { government } \\
\text { employees }\end{array}$ \\
\hline 2 & PB & 32 & Man & 3 years 6 monts & Contract \\
\hline 3 & BT & 29 & Women & 4 years 1 monts & Contract \\
\hline 4 & PI & 35 & Man & 8 years 5 monts & $\begin{array}{l}\text { government } \\
\text { employees }\end{array}$ \\
\hline 5 & AN & 34 & Man & 5 years 7 monts & $\begin{array}{l}\text { government } \\
\text { employees }\end{array}$ \\
\hline 6 & BN & 32 & Women & 4 years 3 monts & $\begin{array}{l}\text { government } \\
\text { employees }\end{array}$ \\
\hline
\end{tabular}

\section{Data collection}

Data collection was carried out through open-ended semi-structured interviews, in which this was done as an ideal setting for bringing out the main themes (Creswell, 2015). Semistructured questions will accommodate in-depth information and help participants define experiences from their perspectives (Smith et al., 2009). The indicators in the interview guide are presented in Table 2.

The interview process begins after participants sign an informed consent indicating a willingness to participate in the study. Interviews took place twice for each participant, with a span of 1-2 weeks. The interview process took place from June-August 2019 and was held at the school where the participants taught, with a mutually agreed time.

All interviews were recorded using a pseudonym and then carried out a verbatim process. Furthermore, the transcript goes through a checking process to see the transcript process's accuracy with voice recordings. 
TABLE 2. Interview guide indicators

\begin{tabular}{ll}
\hline \multicolumn{1}{c}{ Aspect } & \multicolumn{1}{c}{ Indicator } \\
\hline \begin{tabular}{l} 
Experience as a teacher for elementary $\begin{array}{l}\text { school students } \\
\text { schcountered positive experiences }\end{array}$ \\
\cline { 2 - 2 }
\end{tabular} & $\begin{array}{l}\text { Various typical problems faced as millennial teachers } \\
\text { in elementary school }\end{array}$ \\
\cline { 2 - 2 } $\begin{array}{l}\text { The use of technology in learning for } \\
\text { students in elementary schools }\end{array}$ & $\begin{array}{l}\text { Strategies to overcome problems that have been } \\
\text { carried out }\end{array}$ \\
\cline { 2 - 2 } & $\begin{array}{l}\text { Perception of technology as a learning tool } \\
\text { Barriers experienced when integrating technology in } \\
\text { learning }\end{array}$ \\
\cline { 2 - 2 } & Strategies to overcome obstacles encountered \\
\hline
\end{tabular}

\section{Data analysis}

The data analysis process was carried out using the Interpretative Phenomenological Analysis process which explores how the participants interpret their personal and social world. In addition, it is also in how the participants give meaning to specific experiences, events, or circumstances. At the data analysis stage, the researcher carried out three analysis stages; reading the transcript repeatedly, making exploratory comments on the parts deemed important, and developing the main theme.

In the first phase, the researcher made observations and provided an assessment of the subject's experience through a transcript so that the researcher began to integrate with the participants' experiences. Furthermore, the second phase is the process of initial noting and data interpretation. In this phase, the researcher interpreted descriptively by paying attention to narrative details, linguistic by paying attention to the meaning of words (literacy) in the transcript, and conceptual by paying attention to the transcript's interpretation process. The third phase is the process of coding and developing the main theme. The purpose of coding is to identify the categories, relationships and experience assumptions of participants. Coding is also known as the super-ordinate theme (Smith et al., (2009). The main theme consists of super-ordinate themes with similar meanings, which aim to find connections between existing themes. This study's main theme is divided into 4, namely interpersonal experiences, perceptions of technology as a learning tool, barriers to integrating technology in learning and strategies to overcome obstacles.

\section{RESULTS}

The results of the analysis were obtained from the transcripts of the interviews with the subject. Interview transcripts were read repeatedly, made exploratory comments on areas deemed necessary, and developed emergent themes. The analysis results show four main themes, namely interpersonal experience, perceptions of technology as a learning tool, barriers to integrating technology in learning, and strategies to overcome obstacles. The theme of interpersonal experiences, three superordinate themes were found, namely time management during the role of a teacher, the process of establishing a balanced relationship (collegial relationship) and expectations of the millennial generation. In the theme "perception of technology as a learning tool" found two superordinate themes, namely technology to increase student participation and raise students' behavioural problems. The theme of "technology integration barriers" focuses on the challenges or obstacles encountered when integrating technology in learning. In this theme, two superordinate themes were found, namely concerns about cybersecurity and accessibility to technology. The theme of overcoming obstacles focuses on the various strategies that millennial teachers take in overcoming challenges encountered when integrating technology in learning. The superordinate themes found were improving technological skills in learning, technology-human-oriented teaching, involving parents in overcoming problems, and being involved in students' media use activities. The researcher provides a 
notation to make it easier for the reader to understand the subject statement, namely the three-point brackets "[...]"which is used for omitted sentence fragments, while the fourpoint brackets "[....]" used for fragments of one or more sentences, as well as colons "..."is used when there is a break in the subject's speech.

TABLE 3. Results of data analysis

\begin{tabular}{|c|c|}
\hline Main Theme & Super ordinate theme \\
\hline \multirow[t]{3}{*}{ Interpersonal experience } & 1. Time management \\
\hline & $\begin{array}{l}\text { 2. The process of building a balanced relationship } \\
\text { (collegial relationship) }\end{array}$ \\
\hline & 3. Expectations for the millennial generation \\
\hline \multirow[t]{2}{*}{$\begin{array}{l}\text { Perception of technology as a } \\
\text { learning tool }\end{array}$} & $\begin{array}{l}\text { 1. Technology generates interest and increases } \\
\text { student participation }\end{array}$ \\
\hline & 2. Technology raises behavioral problems \\
\hline \multirow{2}{*}{$\begin{array}{l}\text { Barriers to technology } \\
\text { integration }\end{array}$} & 1. Cybersecurity concerns \\
\hline & 2. Accessibility to technology \\
\hline \multirow[t]{4}{*}{ Strategy overcoming obstacles } & 1. Increased technological skills in learning \\
\hline & 2. Technology-human oriented teaching \\
\hline & 3. Involving parents \\
\hline & 4. Engage in students' media usage activities \\
\hline
\end{tabular}

\section{Themes 1. Interpersonal experiences}

This theme focuses on the subjects' experiences related to carrying out their role as millennial teachers in schools. In the theme of interpersonal experiences, three superordinate themes were found, namely time management during the role of a teacher, the process of establishing a balanced relationship (collegial relationship) and expectations of the millennial generation. Participants said that undergoing the profession as a teacher at a young age requires adjustments in managing time and adapting to routine and administrative tasks.

"[....] we have to come to school at 7 am to 4 pm every day. At first, it was really stressful because we had to be in school all that time, I never imagined it would be like this at first [....]" (BT).

“[...]New teachers are usually given many assignments, called administrative tasks, also the teachers must prepare the classroom materials. Finally, time is running out; actually, the teachers should focus on teaching in the classroom, Besides, the teachers have to divide the time by accomplishing on school reports ... we called it "help" [....]" (PB).

Building collegial relationships with senior teachers or from different generations of backgrounds is a condition faced by the participants. Participants are considered to understand more about technology, so they are often asked to do things related to technology integration in classroom learning.

"[....]My age is almost the same as the age of senior's children, there were also students who later became teachers. Can imagine (chuckle) [....]" (PB).

"[....]It takes time, be patient, especially when it comes to work. Often asked to reshuffle the schedule, but it's okay ... so you have to be ready [....]" (BT).

"[....]maybe ee.. because I'm still young, so it is considered I can make and create media... I also asked to make learning media, book learning CDs, make powerpoints, it is considered possible even though it is too overwhelming" (BT). 
"[....]I want that ... Teachers do everything together ... we are learning too, so just do together [....]" (AN).

\section{Theme 2. Perception of technology as a learning tool}

This theme focuses on the subject's perception of technology's role when incorporated into the learning process. In this theme, two superordinate themes were found, namely technology to generate interest and increase student participation and technology to raise students' behavioural problems.

Participants revealed that technology made learning more engaging, easier to understand, and made students more actively involved in learning activities.

"[...]Seeing the benefits, there are many positives, because thanks God, if I see students here, I feel comfortable when the material correlates with technology, They love to be asked to accomplish the assignments by using internet, related to the digital. [....]" $(\mathrm{BN})$.

"[....]However, if students are asked to find information on the internet, it is more attractive. Even they only walked from villages to the Tembalang [....]" (IM)

" [....]teaching today is very different than before, if the teacher only use paper or balckboard as media, the students will be lazy to give attention [...] try using digital media, they are immediately interested [....] " (PI)

"So even if we use YouTube, the students are more interested and enthusiastic in participating the class and the results ... later after watching the video, I usually give some questions and they answer. Children have better memory in watching rather than only reading (chuckles)" (BN)

Besides, the teacher sees the students connected with technology starting from daily life, such as active social media users, permission not to enter school by using the Instagram feature.

"[....]Until my student had never entered and their parents had not had permission, eh, he already permitted via Instagram." (PB).

" [....]All students have social media accounts [...] in class, the children are very fluent with technology features, they are very fast learning ... if a student installs an application, surely the others will ask, I also want to install it." (IM).

"[...] Sometimes I, when I talk about assignments on Facebook ... so the discussion for the assignment is in the comments column." (BT).

"[....]Then one of the children who likes to upload to YouTube [....] then I asked what did you upload? I asked him and he answered "anythings ma'am." (PI).

Besides, the need for connection with learning-related technology looks relatively high.

" [....]They like to use PowerPoint when they are doing presentations, looking for pictures and laptops are a kind of necessity [...]" (AN).

" [....]I have high curiosity, for example, I want to talk about animal adaptation, so I just give the answer $A$... later they will keep asking questions if those $B, C, D$ are what do they look like? So I taught them what kind of lifecycle process, then I will set it from YouTube, so we'll look for it from YouTube [....]" (BT). 
"If by looking at the video instead, the children understand better, work on tasks to be creative, they are also surprised how come they can do that." (AN).

On the other hand, the use of technology can also lead to behavioral problems such as bullying.

"[...] I have experienced related to students' use of Instagram, at Mrs. Mita class, so on Instagram, there are students who posted photos, then continueed to comment each other and finally they fought at school due to misscommunication, and the case folowed up to counselling case." (BN).

"[....] the second one is Facebook, on Facebook and Instagram, there are some students who likes each other [...] then they send their love expression via Instagram, those students were from sixth-grade class and boys at different class [....] It has an effect on social interactions while playing, so they like to make fun of each other. Later, someone will cry, but they will response that it is like "butt hurt"[....]." (BT).

"[....] then if you don't have a social media account you are bullied, you don't play any games, so you will be alone in class. Also, the fifth-grade students start puberty, they like to stalk and flirting via Instagram [...] who uploads what photos on dm, later if you comment, then they will mock everywhere [....]" (AN).

The use of technology is not in line with adequate digital literacy, which causes conflict.

"[...]Y Yesterday, at fifth-grade, I was angry, because a parent got angry ... because of a post by a student of fift-grade to a group that said something like that (pornography), but the others children didn't connect. Because background was like "later if you don't share it, you will be sterile". (AN).

"[...]But the most dangerous is related to the advertisement in Youtube, students shared without knowing the content, so it was a complicated [....]." (IM).

Then, on the other hand, it causes complaints of concentration in class and gives rise to addictive behavior.

" [....]one of the student uses the internet just to play online games, so he is more comfortable with the game than his life and because of the game he doesn't go to school. [....]" (BN).

"so I was provoked by the question, "where are you going on vacation?" Then someone answered that they wanted to go to the DP mall for getting free wifi... others were talking about games." (PB).

“[...]In my class, Ma'am, because of playing games, a student gave less attention to lessons. He only likes drawing pictures and talking about games until I gave him a penalty $[\ldots .] ".(\mathrm{PI})$

"[...] then they are addicted to see and affect the social life at school, decrease of concentration and grades, no enthusiasm, and minimize focus ability. It means that pornography is destructive [....]" (AN).

\section{Theme 3. Barriers to technology integration}


This theme focuses on the challenges or obstacles encountered when integrating technology in learning. In this theme, two superordinate themes were found, namely concerns about cybersecurity and accessibility to technology.

Participants have concerns about the security of platforms or digital media accessed and used by their students.

"I'm worried, especially if the students use Whatsapp and Instagram, which we can not control ... because there is much pornography content that they do not know, which means that pornographic information sometimes packaged as jokes." (PI)

"some students made their own WA group, at earlier entering sixth-grade, they were diligent, active in giving comments at group. After several weeks, I evaluated that some students texted and posted unclear comments whis was incorrelate with the discussion topic, sometimes they used slang words. In my opinion it is not yet suitable to deliver and state at their age." (BT)

"The students like to search assignments' material using YouTube, but sometimes they like to record themesleves and keep upload it on their account ... I'm worries, if an irresponsible person misuses it." (IM)

The next obstacle is accessibility to technology, where the technology facilities available in schools are not adequate yet.

"There is a computer extracurricular activities, but unfortunately, there is no internet connection yet." (BD)

"at fifth-grade, digital usage is not running smoothly, so far we only use LCD and video." (PI)

"For now, not (laughing) because the computers condition are inadequate [...] only a few computers are on." (PB)

\section{Theme 4. Strategies for overcoming obstacles}

This theme focuses on millennial teachers' various strategies in overcoming challenges or obstacles encountered when integrating technology in learning. The superordinate themes found were; improving technological skills in learning, technology-human-oriented teaching, involving parents in overcoming problems, and being involved in students' media use activities.

Participants show awareness of the importance of using technology in teaching and learning activities. This then makes participants carry out certain activities to improve their digital skills. Some took part in multimedia training activities

"When working with a book publisher, they gave a workshop on multimedia, so we participated; they presented a topic." (PI)

"We learn from YouTube, there are many ways of teaching, how to explain the material to make students interested in it ... what media should we use, such as explaining using moving pictures and others." (BT).

"sharing with fellow teachers ... sometimes they will share related to the methods or strategies that can be used in class. Also, we search in google for teaching methods using simple technology." (IM) 
"Internet and others, Insyallah, I can use them because my friends have basic knowledge in IT. Not clueless." (AN)

"Just search on Google for teaching methods using simple technology" (PB)

The knowledge possessed by participants makes them confident when carrying out the teaching process in class, even though with the limited facilities owned by the school. Some make a full effort to use technology in the subjects they teach.

“... so I really take advantage of using social media when learning gymnastics [...], by showing video of gymnastics first, children can imitate it starting from warming up till cooling movements." (PB)

"I will tell you if I open it on YouTube or search on Google [...] I'll show you... the kids will see." (IM)

"For example, about heroes topic, about the history of independence, for example, then I search some references on the internet and then I asked them to find out more." (BT)

"Well, I will also tell the children, for example a lesson about the Prophet of Musa, now the kids just type the Prophet Musa on YouTube search." (BN)

There are also those who do not fully use technology but provide it as a variation in learning methods.

"I only downloaded and used videos, music, and ppt from the internet." (PI)

"I only gave the assignment to the students to search pictures from books, magazines, the internet, or other resources for learning." (BT)

"I integrated technology in teaching as inetremezzo during class, for example the topic is weather, then I played video from youtube. [...] I also asked students to bring flashdisc to get learning materials from me, I'll copy it." (IM)

Furthermore, teachers use social media's content as a medium of learning, such as use updated news, articles, videos, and others.

"for example the subject was Bahasa Indonesia and the topic was "story", I used the content from Instagram related to game addict or offensive language, then I gave questions and discussed it." (PI)

"I upload story in instagram feed at least once a day because there is such a challenge to make a story. You can just search for \#catatanalan, the stories are random." (AN)

Using email and Whatsapp are popular applications to be used as a medium of communication between teachers and parents. When giving assignments, the teacher share informations to parents, it aims to give understanding to the parents related to childrens' assignments. This is also because the students use parents' handphones and laptops to learn.

"For information such as competitions flyer, I usually share information via email because the size of documents is large." (PI)

"here, we have many Whatsapp group, ma'am ... we usually communicate using WA. [....] there are already 3 official services, also alumni and parents groups." (PB) 
"Because parents nowadays are familiar with gadgets ... while the kids forget to give official letter from school, we will use Whatsapp group to share the information[......" (BT)

"especially for busy parents ... before being asked, I was ready to prepare the materials learning by scanning and taking photos first [...] then, I just need to upload and share it again." (BN)

"I also share assignments to the parents' group, as well as they can ask questions, sometimes they tell that their children are interested and enthusiastic using the Internet, sometimes, parents also ask... Sir, how to search something on Google." (AN)

WhatsApp is also a medium for parents to consult or tell about their child's condition as well as media for teachers to educate parents in using technology media for children.

"then parents also share related to the their children fifficulties or all about learning by whatsapp [....] then, we respond them via private chat, [....] If the parent complaints they will use private chat to avoid bigger problems." (BT)

"we also give restrictions to parents about the use of the Whatsapp for children and most of them ... um, maybe 50\% have limited to use it and block inappropriate networks." (PB)

In addition, participants or teachers also tried to be actively involved in the digital lives of their students by opening Instagram accounts as an effort to monitor students' virtual world activities.

"I also follow students' instagram because I want to know the students' feed or story [....] if their posts are good then I give code "like" to them, sometimes I comment." (BN)

"I use Instagram specifically for children and teachers [....] My Instagram is also usually related to schools stories; for motivation ... for example ... I uploaded the news about the winner of school's competition [...] activities at school ... hopefully it will make students know about upadated news from school and encourage their notivation...." (IM)

Also by being involved in the class WhatsApp group.

"So in every class there is a WhatsApp group, huh ... maybe the teacher knows better ... it is as media for students' monitoring [...] later, usually all children's activities that we really need to know ... can be monitored from there." (PB)

“...but there are a lot of children at home who have been facilitated by cellphones [...] they make their own groups, the teachers also involved in that group ... so I can also monitor what they are talking about." (BT)

\section{DISCUSSION}

In this study, it was found that the interpersonal experiences that millennial teachers encountered during their roles were related to time management, the process of establishing a balanced relationship (collegial relationship) with students and expectations of the millennial generation. It is in line with previous research that the 
challenge faced by teachers besides work pressure is the ambiguity of roles in education; where there is a dual role as a teacher and executor of administrative tasks so that it takes time to adapt (Alontaga dan Durban, 2013; Mark, Wang, \& Niiya, 2014). Meanwhile, in another study, it was stated that the millennial generation has a desire to have free time and activities related to relaxation. It is (DeVaney, 2015) making millennial generation teachers experience discomfort or difficulty working with long working durations. Millennial character is constantly questioning what for, why do they do something (Twenge, 2009). Thus, attendance requirements, expectations of ability and willingness to do something are conflict situations faced by the subject. Based on these conditions, it is necessary to have open communication between school principals and policyholders regarding working hours and workload for millennial teachers.

In interpersonal relationships, millennials participate actively and want collegial, collaborative relationships, thus rejecting traditional leadership styles (Kuron, Lyons, Schwitzer, \& Ng, 2015). It arises from the subject's desire to have peer-to-peer relationships with teachers who are considered senior in the school environment. They want a more flexible relationship to make an active contribution to the school's progress (DeVaney, 2015).

Deyoe dan Fox (2011) emphasized that millennials' differences in expectations, treatment, and values with previous generations in the workplace can increase conflict. The research findings indicate an imbalance in the relationship between subjects and previous generations needs essential attention. Interaction with fellow teachers is an important thing that needs to be considered to create quality involvement and relationships. Positive relationships will increase satisfaction and meaning and increase millennial participation in achieving the goals that have been set (E. Kim \& Corcoran, 2018). It also helps millennial teachers in shaping professional teacher personality patterns (Darling-Hammond, 2017).

In this study, it was found that the integration of technology in learning carried out by millennial teachers generated a sense of interest and increased student participation. This study's results reinforce previous research where digital technology's involvement as an innovation in learning will improve cognitive abilities and creative thinking (Cavanaugh, Giapponi, \& Golden, 2016), problem solving and communication skills (Darling-Hammond, Wilhoit, \& Pittenger, 2014). Innovative teachers focus not only on one method but also on developing several platforms used in learning (Al-Ani, 2015; Koehler \& Mishra, 2005). It can be seen from the teacher's efforts to incorporate several digital tools into classroom materials, including videos obtained from YouTube and Google's images in learning materials. Students also become creative in doing assignments when using digital technology as materials and media. However, there is a negative side found in this study regarding the use of technology in the classroom, namely raising students' behavioural problems. This is in line with previous research, which found that experience with digital technology makes it difficult for millennials to adapt when placed in an environment that does not facilitate this (Walker, 2011).

Furthermore, this study found that there are concerns about cybersecurity and accessibility to technology due to the limitations of schools' technology. For students, the use of digital technology is an important requirement (Williams, Medina, Medina, \& Clifton, 2017). So that the limitations of school facilities are seen as an obstacle in integrating technology in learning materials. The things that have been done to overcome various obstacles in using technology are providing technology skills in learning, technology-human-oriented teaching, and being involved in students' media use activities. Providing technological skills in learning can increase teacher self-efficacy. Teacher confidence and self-efficacy levels play a significant role in integrating technology in academic settings (Liu, Ritzhaupt, Dawson, \& Barron, 2016; Overbaugh, Lu, \& Diacopoulos, 2015). Liu et al. (2016) also emphasized that teaching experience contributes significantly to teacher confidence in the use of digital technology in the classroom. In addition, the familiarity and experience of using technology such as computers and online media play 
an important role in the frequency and variety of use of digital media in the classroom (Harcourt, 2017).

Another strategy that can be done is to involve parents in overcoming problems. This also affects teacher-parent interactions, such as the use of online communication platforms (Harcourt, 2017) as found in research subjects who use WhatsApp and email as a medium of communication with parents. The interaction between teachers and students also becomes close where the teacher tries to be involved in their students' digital life activities. Associated with the technology adoption process in learning, the subjects in this study have experienced a knowledge and persuasion phase, where according to their characteristics as millennials, the subject feels the importance of integrating digital technology in learning. The decision-making process is accompanied by the consideration that students will be more interested in being involved in learning if they include digital technology. Inadequate facilities, low digital literacy of students and the negative impact of using digital technology are the subject's considerations in implementing learning innovations and their digital behavior. In the confirmation phase, through their relationship with students' reactions when given assignments, interaction with students on social media accounts, and parental responses through digital communication platforms, subjects confirmed the given learning method's success.

\section{CONCLUSION}

The results showed that millennial teachers have the value of collaborative and collegial work. Flexible working relationships will help them to make an active contribution at work. This study also reveals that one of the problems that millennial teachers encounter during their role is related to bad time management due to high workloads. So, school principals and policyholders can overcome these problems by building open communication patterns with millennial teachers. The use of technology that is integrated into learning is considered to increase student interest in subjects, but the limitations of school facilities and the limited understanding of teachers are still obstacles encountered. Some things that can be done are providing skills to teachers about technology, involving parents in the learning process, and establishing relationships and monitoring student activities through social media. This study uses a qualitative study with limited research subjects (6 subjects) so that further research can be carried out using quantitative methods to see the extent of millennial teacher problems' dynamics. Also, further research can be developed with experimental methods to improve skills in using technology for teachers.

\section{ACKNOWLEDGEMENT}

Researchers would like to thank the Institute for Research and Community Service of Diponegoro University, Semarang for funding this research through the International Publication Research scheme.

\section{REFERENCES}

1. Al-Ani, W. T. (2015). Blended learning approach using moodle and student's achievement at Sultan Qaboos University in Oman. Journal of Education and Learning, 2(3), 96-110. https://doi.org/10.5539/jel.v2n3p96

2. AlontagaJ.\& Durban, J. (2013). A self-assessment of the professional among elementary school teachers. European Social Science Research Journal, 1(1).

3. Attard, C., \& Orlando, J. (2014). Early career teachers, mathematics and technology: Device conflict and emerging mathematical knowledge. Curriculum In Focus: Research Guided Practice: Proceedings of The 37th Annual Conference of The Mathematics Education Research Group of Australia (Merga 37), Aerial Centre, The University of 
Technology, Sydney, NSW, Australia, 71-78.

4. Batz, Z., Olsen, B. J., Dumont, J., Dastoor, F., \& Smith, M. K. (2017). Helping struggling students in introductory Biology: A peer-tutoring approach that improves performance, perception and retention. CBE- Life Sciences Education, 14, 1-12. https://doi.org/10.1187/cbe.14-08-0120

5. Bennett, V. M., \& Levinthal, D. A. (2017). Firm lifecycles: Linking employee incentives and firm growth dynamics. Strategic Management Journal, 38(10). https://doi.org/10.1002/smj.

6. Cavanaugh, J. M., Giapponi, C. C., \& Golden, T. D. (2016). Digital technology and student cognitive development: The neuroscience of the University Classroom. Journal of $\begin{array}{lll}\text { Management } \quad \text { Education, } & \text { 30(4), }\end{array}$ https://doi.org/10.1177/1052562915614051

7. Chiu, T. K. F., \& Churchill, D. (2015). Exploring the characteristics of an optimal design of digital materials for concept learning in mathematics: Multimedia learning and variation theory. Computers \& Education, 82, 280-291. https://doi.org/10.1016/j.compedu.2014.12.001

8. Coomes, M. D., \& Debard, R. (2004). Serving the millennials generation: New directions for student services. San Fransisco: CA: Jossey-Bass.

9. Creswell, J. W. (2015). Educational research: Planning, conducting, and evaluating quantitative and qualitative research. New York: Pearson Education.

10. Darling-Hammond, L. (2017). Teacher education around the world: What can we learn from international teacher education around the world: What can we learn from international practice ? European Journal of Teacher Education, 40(3), 291-309. https://doi.org/10.1080/02619768.2017.1315399

11. Darling-Hammond, L., Wilhoit, G., \& Pittenger, L. (2014). Accountability for college and career readiness developing a new paradigm. Education Policy Analysis Archives, 22(86). https://doi.org/dx.doi.org/10.14507/epaa.v22n86.2014

12. DeVaney, S. (2015). Understanding the millennial generation. Journal of Financial Service Professionals, 69, 11-14. Retrieved from https://www.scirp.org/(S(lz5mqp453edsnp55rrgjct55))/reference/ReferencesPaper s.aspx?ReferenceID=2035957

13. Deyoe, R. H., \& Fox, T. L. (2011). Identifying strategies to minimize workplace conflict due to generational differences. Journal of Behavioral Studies in Business, 41, 1-17. Retrieved from http://www.aabri.com/SA12Manuscripts/SA12102.pdf

14. Dimmock, M. (2019). Defining generations: Where millennials end and generation $Z$ begins. Retrieved from Pew Research Center website: https://www.pewresearch.org/fact-tank/2019/01/17/where-millennials-end-andgeneration-z-begins/

15. Ertmer, P. A., Ottenbreit-Leftwich, A. T., Sadik, O., Sendurur, E., \& Sendurur, P. (2012). Teacher beliefs and technology integration practices: A critical relationship. $\begin{array}{llll}\text { Computers \& Education, 423-435. } & \text { 42), }\end{array}$ https://doi.org/10.1016/j.compedu.2012.02.001

16. Flanagan, S., \& Shoffner, M. (2013). Teaching with(out) technology: Secondary english teachers and classroom technology use. Contemporary Issues in Technology and Teacher Education, 13(3), 242-261.

17. Harcourt, H. M. (2017). Teaching K-12 literacy in a digital world. UCLA: HMH Author and Associate Director, California Reading \& Literature Project.

18. Horn, M. B., Staker, H., \& Christensen, C. M. (2014). Blended: Using disruptive innovation to improve schools. In The Chsristensen Institute. Retrieved from http://www.wiley.com/WileyCDA/WileyTitle/productCd-1118955153.html.

19. Howe, N., \& Strauss, W. (2000). Millennials rising: The next generations. New York: Vintage Books.

20. Joiner, R., Gavin, J., Brosnan, M., Cromby, J., Gregory, H., Guiller, J., Moon, A. (2013). Comparing first and second generation digital natives' internet use, internet anxiety 
and internet identification. Cyberpsychology, Behavior, and Social Networking, 16(7). https://doi.org/10.1089/cyber.2012.0526

21. Kaifi, B. A., Nafei, W. A., Khanfar, N. M., \& Kaifi, M. M. (2012). A multi-generational workforce: Managing and understanding millenials. International Journal of Business and Management, 7(24), 88-93. https://doi.org/10.5539/ijbm.v7n24p88

22. Keren-kolb, L. (2013). Engage, enhance and extend learning! Learning \& Leadning with Technology, 5191, 20-27. Retrieved from https://eric.ed.gov/?id=EJ1015177

23. Kim, C., Kim, M. K., Lee, C., Spector, J. M., \& DeMeester, K. (2013). Teacher beliefs and technology integration. Teaching and Teacher Education, 29, 76-85. https://doi.org/10.1016/j.tate.2012.08.005

24. Kim, E., \& Corcoran, R. P. (2018). Factors that influence pre-service teachers' persistence. Teaching and Teacher Education, 70, 204-214. https://doi.org/10.1016/j.tate.2017.11.015

25. Kirkwood, A., \& Price, L. (2014). Technology-enhanced learning and teaching in higher education: What is 'enhanced' and how do we know? A critical literature review. Learning, Media and Technology, 39(1), 6-36. https://doi.org/10.1080/17439884.2013.770404

26. Klassen, R. M., Frenzel, A. C., \& Perry, N. E. (2012). Teachers' relatedness with students: An underemphasized component of teachers basic psychological needs. Journal of Educational Psychology, 104(1), 150-165. https://doi.org/10.1037/a0026253

27. Koehler, M. J., \& Mishra, P. (2005). What happens when teachers design educational technology? The development of technological pedagogical content knowledge. Journal Educational Computing Research, 32(2), 131-152. https://doi.org/10.2190/0EW7-01WB-BKHL-QDYV

28. Kuron, L. K. ., Lyons, S. T., Schwitzer, L., \& Ng, E. S. . (2015). Millennials' work values: Differences across the school to work transition. Personal Review, 44(6), 991-1009. https://doi.org/10.1108/PR-01-2014-0024

29. La Kahija, Y. F. (2017). Penelitian fenomenologis jalan memahami pengalaman hidup. Yogyakarta: Kanisius.

30. Laughter, J. C. (2011). Rethinking assumptions of demographic privilege: Diversity among white preservice teachers. Teaching and Teacher Education, 27(1), 43-50. https://doi.org/10.1016/j.tate.2010.07.001

31. Liu, F., Ritzhaupt, A. D., Dawson, K., \& Barron, A. E. (2016). Explaining technology integration in K-12 classrooms: A multilevel path analysis model. Educational Technology Research and Development, 65(4), 795-813. https://doi.org/10.1007/s11423-016-9487-9

32. Mark, G., Wang, Y., \& Niiya, M. (2014). Stress and multitasking in everyday college life: An empirical study of online activity. Proceedings of the 32nd Annual ACM Conference on Human Factors in Computing Systems - CHI '14, 41-50. https://doi.org/doi: $10.1145 / 2556288.2557361$

33. Overbaugh, R. C., Lu, R., \& Diacopoulos, M. (2015). Changes in teachers' attitudes toward instructional technology attributed to completing the ISTE NETS*T certificate of proficiency capstone program. Computers in the Schools, 32(3-4), 240-259. https://doi.org/10.1080/07380569.2015.1059254Shatto, B., \& Erwin, K. (2016). Moving on From Millennials: Preparing for Generation Z. Journal of Continuing Education in Nursing, 47(6), 253-254. https://doi.org/10.3928/0022012420160518-05

34. Silverman, D. (2010). Doing qualitative research: A practical handbook (3rd Edition). London: Sage Publications.

35. Smith, D. (2013). Husserl: 2nd revised edition. London and New York: Routledge.

36. Smith, J., Flowers, P., \& Larkin, M. (2009). Interpretative phenomenological analysis: Theory, method and research. California: Sage Publications.

37. Staker, H., \& Horn, M. B. (2012). Classifying K-12 blended learning. California: 
Innosight Institute.

38. Twenge, J. M. (2009). Generational changes and their impact in the classroom: Teaching generation me. Medical Education, 43(5), 398-405. https://doi.org/10.1111/j.1365-2923.2009.03310.x

39. Ulfah, S. (2016). Pengaruh komitmen dan kecerdasan emosional terhadap kinerja pegawai melalui kepuasan kerja sebagai variabel intervening (Studi kasus pada sekretariat daerah Kabupaten Jepara). Universitas Muria Kudus.

40. Van-Manen, M. (2014). Phenomenology of practice: Meaning-Giving methods in phenomenological research and writing. California: Left Coast Press.

41. Walker, G. (2011). The changing face of international education. Cardiff: International Baccalaureate.

42. Williams, V. N., Medina, J., Medina, A., \& Clifton, S. (2017). Bridging the millennial generation expectation gap: Perspective and strategies for physician and interprofessional faculty. The American Journal of the Medical Sciences, 353(2), 109115. https://doi.org/10.1016/j.amjms.2016.12.004

\section{PROFILE}

Dian Veronika Sakti Kaloeti is a lecturer at the Faculty of Psychology, Diponegoro University. She is also the editor in chief of the Jurnal Psikologi of Diponegoro University, a reviewer for several accredited national journals and reputable international indexed journals. She is active in conducting research and obtaining national and international funding grants with the theme of resilience to various age groups, one of which is children, as well as the relationship between psychology and digital technology in various aspects of life.

Rouli Manalu is a lecturer in the Communication Studies Program at the Faculty of Social and Political Sciences, Diponegoro University. She is active in conducting research and obtaining national and international funding grants on the development of communication technology, communication and social change. 